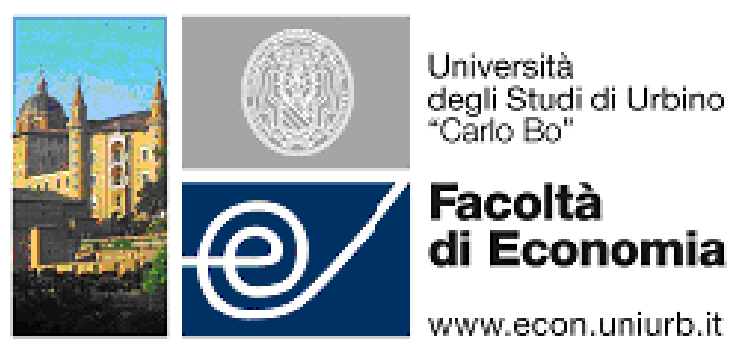

WP-EMS

Working Papers Series in Economics, Mathematics and Statistics

"Towards a Program for Financial Stability"

- Robert E. Krainer (University of Wisconsin-Madison) 


\title{
TOWARDS A PROGRAM FOR FINANCIAL STABILITY
}

\author{
Robert E. Krainer \\ University of Wisconsin-Madison \\ 975 University Avenue \\ Madison, WI 53706-1323 \\ rkrainer@bus.wisc.edu \\ Phone: (608) 263-1253 \\ Fax: (608) 265-4195
}

August 2009

This Draft: March 2010

KEY WORDS: Financial Stability, Narrow Banking, Open Market Operations in Equities, Selective Credit Controls 


\title{
TOWARDS A PROGRAM FOR FINANCIAL STABILITY
}

\begin{abstract}
Fifty years ago Milton Friedman published a book entitled A Program for Monetary Stability. In it he outlined a number of suggestions for the conduct of monetary and fiscal policies that he thought would contribute to monetary stability and pari passu to price stability and a greater degree of output/employment stability. In this paper I review some of his policy prescriptions in light of the financial and economic crisis of 2007-2009. From the perspective of financial development the world today is much different from the world that Friedman knew in the late 1950's. In what way would his policy recommendations have to be modified to account for these changes in financial development? To stabilize the banking system we argue that his proposal for 100 percent reserves or narrow banking merits serious consideration in current policy discussions. To stabilize asset markets we propose two policies that Friedman would not likely endorse. The first is to reinstate selective credit controls in the areas of the securities markets and the real estate market. The second policy designed to dampen excessive variability in the stock market is for the Central Bank to carry out some open market operations in an index fund of equities.
\end{abstract}

JEL Classification E32, E44, E52, G18, G21 


\section{INTRODUCTION}

Over a half of a century ago Milton Friedman gave a series of lectures at Fordham University that were subsequently published under the title of A Program for Monetary Stability (1959) with a new preface added in 1992. In it he outlined a number of suggestions for the conduct of monetary and fiscal policies that he thought would contribute to monetary stability and pari passu to price stability and a greater degree of output/employment stability. In this paper I review some of his policy prescriptions in light of the financial and economic crisis of 2007-2009. The goals of policy are the same today as they were in his day. The question is would his policy prescriptions in the late 1950's have prevented or substantially blunted the financial and economic crisis that began to unfold in 2007? Of course from the perspective of financial development the world is very different today compared to when Friedman wrote. Would the financial development that has taken place between then and now render his policy recommendations obsolete? In what ways would his policy recommendations have to be modified to account for these changes in financial development? These are interesting questions that deserve further attention alongside the numerous proposals that have recently been offered by financial economists to further regulate our financial system.

Friedman made a number of suggestions for policy reform in the Program for Monetary Stability. Some of his suggestions were subsequently adopted, but most were not. Interesting examples of the latter, in light of the current crisis, include eliminating 
discounts and advances as an instrument of monetary policy, requiring banks to hold reserves equal to 100 percent of their deposit liabilities ${ }^{1}$, and having the Federal Reserve (through open market purchases of government securities) follow a k-percent per year (or, 1/12 k-percent per month) rule of steadily increasing the money supply. An equally interesting example of the former includes allowing the Federal Reserve to pay interest on reserve balances held by the member banks. This policy change was implemented in October 2008 and revised in December 2008.

The three controversial proposals for monetary reform that were not implemented had as their objective the reduction of the volatility in the growth rate of the money supply. According to Friedman business cycles were caused by uncontrollable outside disturbances and very controllable disturbances in the money supply. For him the modest objective of monetary policy, as far as business cycles were concerned, should be to reduce the inter-temporal volatility in the money supply which in turn would reduce the controllable part of the volatility in real output and employment. What has actually happened with respect to these three suggestions since Friedman gave these lectures? In terms of the financial crisis of 2007-2009, discounts and advances -which he advocated should be eliminated - actually played a key role in the Federal Reserve's strategy to liquefy the financial system. One element of this strategy was to lower the investment quality of the collateral the Federal Reserve would accept from eligible borrowers. The second part of their strategy was to open up discounts and advances to non-bank borrowers. The end result of this strategy to combat the crisis was that the assets of the Federal Reserve rose from $\$ 870$ billion before the financial crisis to $\$ 2$ trillion as of April 
3, 2009. ${ }^{2}$ As far as the Friedman-Simons proposal for a 100 percent legal reserve requirement on bank deposits was concerned, they have in fact fallen. When Friedman gave his lectures the legal required reserve ratio on net demand deposits was 18 percent for Central Reserve City banks, 16.5 percent for Reserve City banks, and 11 percent for Country banks. The three categories of banks were subsequently reduced to one (as recommended by Friedman) and presently the requirement is 10 percent on demand deposits over $\$ 44.4$ million for all depository institutions. Furthermore the effective reserve ratio is actually smaller due to the fact that banks are allowed to sweep portions of their customer demand deposits into investment accounts (for which the required reserve ratio is -0- percent ) overnight and on the weekends. Finally, what about his kpercent rule designed to stabilize the growth rate of the money supply? From 1959 when the lectures were originally published to 1992 when he appended an additional preface, the average percentage growth rate and standard deviation of the growth rate for M1 were respectively .063 and .036. From 1992-2007 the average growth rate and standard deviation of the growth rate for M1 were .028 and .051 . On average the Federal Reserve reduced the growth rate in M1 but increased its volatility in the later period compared to the earlier period. According to Friedman and the quantity theory of money the 55 percent reduction in the average growth rate of $\mathrm{M} 1$ should be reflected in a 55 percent lower average inflation rate. That in fact turned out to be approximately the case. The average rate of change in the GDP deflator as a measure of price inflation was .044 over the period 1959-1992 and fell to .022 for the period 1992-2007 for a reduction of 50 percent providing modest support for the quantity theory of money. Moreover the standard deviation in the growth rate of the GDP deflator fell from .025 over the period 
1959-1992 to .006 in the period 1992-2007. Thus an over 40 percent increase in the standard deviation of the growth rate in M1 (i.e., from .036 to .051) was accompanied by an over 75 percent reduction in the standard deviation (i.e., from .025 to .006) of the GDP inflation rate. This may not be consistent with the quantity theory. In any event the actual average inflation rate was both lower and on average more stable in the period 1992-2007 compared to the period 1959-1992. What about real output as measured by real GDP? Recall that the objective of the k-percent rule was to stabilize monetary growth which according to Friedman would reduce that part of the business cycle caused by monetary instability. What actually happened? The average growth rate in real GDP was .035 in the period 1959-1992 and that fell slightly to .031 in the period 1992-2007. The variability of real GDP growth also fell between the two periods which is seemingly at variance with Friedman's prediction based on the increased variability in the money supply that actually occurred in the later period. The standard deviation of the real GDP growth rate was .023 in the period 1959-1992, and fell to .011 in the period 1992-2007. Many financial economists during the latter time period argued that the reduction in the volatility of real GDP (a proxy for macroeconomic risk facing companies) ushered in a new era of economic stability thereby warranting an increase in financial leverage and financial risk. Unfortunately many financial and non-financial enterprises acted on this advice with disastrous consequences in the period 2007-2009. While neither of Friedman's policy reforms on reserve requirements or the k-percent rule designed to stabilize monetary growth were actually implemented, inflation and output growth on average behaved as if they were right up to the beginning of the financial crisis. But the whole story is not told by merely comparing averages for 1959-1992 to 1992-2007. The 
average growth rate for M1 for the three year period 2005-2007 was a -.0023 compared to .052 for the previous three year period 2002-2004. According to Friedman the sharp contraction in M1 should, with a lag, cause a subsequent decline in real GDP, which in fact actually occurred in 2008-2009. Some economists have asserted that this abrupt contraction in the money supply that drove up borrowing costs for home buyers was an important factor in causing the end of the housing bubble and triggered the beginning of the financial and economic crisis that began in 2007.

Had the Friedman-Simons structural reform of the banking system been implemented, would it have prevented the 2007-2009 financial and economic crises? Setting aside the sharp contraction in M1 growth in the three year period prior to the crisis - which Friedman would argue in itself would cause a recession--there is reason to believe that the precipitating financial crisis would have at least been somewhat moderated. To begin with, on the supply side narrow banks with a 100 percent reserve requirement would no longer have been involved in the financing of what turned out to be toxic assets. The real question is whether other non-bank financial institutions (the so-called shadow banking system) financed with uninsured claims, would have arisen in place of the banks to fund on the same scale the risky real assets being acquired by households and firms in the runup to 2007? It would seem that the answer to this question would be: No. Without a risk-free government insurance program behind the claims financing these non-bank financial institutions, risk averse savers would require a higher expected return relative to what they would require on insured deposits in present day banks. This higher required rate of return of savers would translate to a higher cost of capital and thereby dampen some of the demand for debt financed risky real assets by firms and households in the 
run-up to 2007. How much savers required rate of return would have increased and how much this increase would decrease the demand for risky real investments by households and firms are empirical questions which have not been answered at this point. In any event the end result would have been more moderate economic growth in the run-up period accompanied by less speculative debt financing both of which would have moderated the crisis beginning in 2007.

The current fractional reserve banking system with deposit insurance, where banks are also risk-taking financial intermediaries, has resulted in a cost of capital reduction subsidy to households and risky firms and a larger stock of risky capital. It would seem that this set of financial arrangements would contribute to a more volatile rate of economic growth that would depend in part on how aggressive banks are in their portfolio decisions. Banks in this set of financial arrangements amplify cyclical expansions when they ease lending standards but also amplify cyclical recessions when they tighten lending standards in a flight to safety. ${ }^{3}$ The policy question is whether the upside amplification of the real economy is worth the downside amplification. Net present value calculations of "highs" minus "lows" would seem to be a way to address this policy issue but this kind of calculation typically depends on the economic position of different agents and their discount rates during the highs and lows of the economy.

Friedman's Program was primarily designed to stabilize the growth in the stock of money in the hope of achieving a greater degree of macroeconomic stability. His view was to let the private sector in the form of non-bank financial intermediaries and financial markets steer the savings of society into productive investment. Let the private sector make the risky investments and reap the profits or suffer the losses without any 
government regulation or intervention. With the exception of his proposal for narrow banking this also was the overriding view of the Federal Reserve for at least the past 25 years. The objective of policy was to free-up the financial system from depression era regulation and allow the financial engineering that had been occurring since the 1980's to create a new financial architecture that would reduce risk per unit of return through such products as portfolio insurance, credit default swaps and other contingent claims, and various types of securitization schemes. Both Friedman and the Federal Reserve would think it inconceivable that private agents guided by self interest would develop and manage financial instruments and architectures in a way that would destroy their own wealth and bring down that architecture. One popular view of the financial crisis is that this is what actually happened starting in 2007 . But was it only ignorance of the complex contingent claims that were created, blind greed, and flawed compensation schemes that brought down the banking system in 2007-2009 as so often is said? A case could be made that banks were merely implementing the portfolio strategies that bank stockholders were asking for. In the 5 year run-up to 2007 the S\&P bank stock index was on average rising at the rate of 7 percent per year spurred on by a fall in investor risk aversion and perceptions of risk. ${ }^{4}$ The market signal was for banks to take on riskier investments as their cost of capital fell, and this is what they did. This is not to say that their compensation schemes were not flawed and contributed to their investment in risky assets, or, that complex opaque securities that were not well understood were created out of that architecture. It is merely to say that optimal investment decisions in the face of a falling cost of capital could also account for banks taking on ever riskier investments in the run-up period. Therein lies the dilemma for banks. Checkable deposits are an 
important component of the money supply that facilitates economic exchange. In this capacity banks from the perspective of society can't risk failure for fear of causing a collapse in economic exchange and the social unrest that comes with the resulting recession. For that reason governments insure bank deposit liabilities. Presently banks are also profit maximizing financial intermediaries. ${ }^{5}$ In this capacity it is legitimate for them to make risky investments and thereby risk bankruptcy as they solve the "lemons" problem of asymmetric information between investing firms and ultimate savers. To the extent they perform this intermediary function efficiently, they facilitate long-run economic growth according to conventional theory. These two functions of safeguarding deposit money and successful but risky intermediation are basically incompatible. The Friedman-Simons proposal for 100 percent reserves is one solution to this problem in a step towards financial stability. The goal for the rest of this paper is to move beyond Friedman's proposals for monetary stability to consider a Program for Financial Stability.

\section{TOWARDS A PROGRAM FOR FINANCIAL STABILITY The Case for Narrow Banking}

Any reform of the financial system must begin with the banking system. For the most part regulation has focused attention on both the asset side and the liability and equity side of the balance sheet of banks. The 100 percent reserve or narrow banking system proposes to further regulate the asset side of the balance sheet. ${ }^{6}$ The arguments in favor of a 100 percent reserve system, or the narrowest of narrow banking, go beyond the Friedman-Simons goal of stabilizing the growth rate of the money stock. To begin with it 
is difficult to understand in the first place why it is optimal for 53 percent of transactions balances (the currency proportion of M1 on June 1, 2009) to be defined as legal tender by the government and therefore riskless while 46 percent (the demand deposit proportion) is subject to some risk. Ever since the Great Depression of the 1930's the transaction mechanism underlying our money economy has relied on the banks' pledge to convert the par value of checking account money into currency money on demand, and to transfer on demand and at par the deposits of agents in one bank to agents at another bank. When banks can't honor that pledge then to maintain the integrity of the payments system a government insurance agency like FDIC steps in to partially or wholly honor the pledge. In order to minimize insurance payouts to depositors of bankrupt banks, the FDIC and other regulators monitor the balance sheets of banks. This monitoring is difficult and costly since many of the investments on the banks' balance sheets are opaque. If public policy requires that both checking account money and currency money be transferable and convertible on demand for purposes of carrying out transactions, why allow banks to make risky and opaque investments and then go through the costly process of monitoring those investments and insuring the deposits that finance them in order to facilitate an orderly transaction mechanism?

Perhaps the best cost reduction solution in the narrow bank proposal would be for the government to supply checking account money through an agency like the Central Bank or post office. There are historical precedents for both although post office banks have been more popular. Checks (or debit entries) on the Central Bank or post office along with currency would then become legal tender in the discharge of debts. From a facilities location point of view would it be possible to implement these two government- 
based narrow banks? In terms of numbers there were 7,842 banks (and falling) in 2003 with approximately 68,000 branches (and rising) in the U.S. ; and private estimates put the number of post offices at $187,000 .^{7}$ It would appear that the number of separate post offices would be more than adequate to replace existing banks and their branches with post office-based narrow banks. For a Central Bank based narrow bank the transition would be more difficult. They could buy some of the branches of conventional banks as some of them would become redundant under the new system. Alternatively they could rent space for retail kiosks in existing post offices or any retail store for that matter. In both schemes there would be a need to redesign existing facilities and build new ones to better match the location of retail banking customers. There are a number of advantages of a government-based narrow banking system. One advantage is simplicity. All that would have to be done is to provide the necessary facilities and architecture to carry out narrow banking, and with advanced planning the elimination of deposit insurance on present day bank deposits. A second advantage of a government-based narrow banking system at the retail level is that checking account money would become national money like currency rather than local money as bank checks for the most part currently are. A third advantage is that it would be more difficult to undo than a narrow-based system comprised of private banks. Private banks in the past have been successful in undoing government regulation and there is every reason to believe that whatever new regulation that occurs in response to the current crisis will eventually be undone in less turbulent times. What would happen to existing banks? ${ }^{8}$ They would become non-bank financial intermediaries of their own choosing and their shares or claims to assets would not be insured, at least by the government. It might be argued in opposition to this solution that 
a government-based narrow banking system would be slow to introduce new technologies that reduce the cost of producing checking account services. Therefore one reason for having private but narrow banks supply checking account money is presumably because of the profit incentive to innovate. ${ }^{9}$

While a government-based narrow banking system would be the first best solution in designing a program for financial stability, most of the past proposals for narrow banking assume they would be carried out within the framework of private banks. What advantages would accrue to a private or public based narrow banking system? To begin with under a system of narrow banking there would be no need for government regulation or deposit insurance except to protect depositors from fraud and other forms of malfeasance. Reserve balances, vault cash, or even T-Bills need little monitoring and the monitoring that would be required would be relatively low cost compared to the cost incurred in our present system. Costly supervision and monitoring of banks would therefore be greatly reduced. It would also be the case that narrow banks would not need risk-based capital requirements as is now required under the Basle Accord. Since banks would only hold risk-free assets the equity or tier 1 capital required would be $4-5$ percent of total assets under present requirements.

A second argument for separating the deposit supplying function from the financial intermediation function of banks has to do with attaining the standard goals of monetary policy. An unexpected banking crisis under the current banking system may redirect the monetary policy of the Central Bank towards resolving the banking crisis and away from achieving a pre-existing goal such as price stability and in the process make that goal even more difficult to achieve. The problem is that governments have only two 
instruments (monetary and fiscal policy) to achieve three targets; financial stability, employment/output stability, and price level stability. That would seem to be the dilemma Central Banks find themselves in 2009. The 230 percent growth in the balance sheet of the Federal Reserve as a result of addressing the financial crisis carries with it the danger of increased future inflation. The bond market recognizes this danger and in mid2009 the yield on 10 year T-Bonds rose to 3.72 percent compared to 2.42 percent at the end of 2008. Accordingly regulation should be the means to achieve financial stability.

A third advantage of narrow banking would be to price checking account services more efficiently. The provision of these services would become a more important source of revenue for narrow banks and they would price them more closely to costs. Presently the cost of checking account services is concealed to the deposit customers of banks by the interest rate spread between lending and investing rates of interest and the rates paid on deposits. As a result the deposit customer has little knowledge of the true cost of holding checking account money. Consequently depositors may be consuming too much or too little of checking account services.

The most important benefit of narrow banking would be a more efficient allocation of real investment in the economy. A Pareto efficient allocation of real investment is one where the marginal rate of substitution of return for risk in the preference functions of savers equals the marginal rate of transformation of return for risk in the technology of investing firms. This is not the case in our current financial system with deposit insurance for banks. Banks obtain most (roughly 65 percent) of their investible funds from depositors. Because deposits (both checkable and non-checkable) are deemed to be important in the functioning of the real economy, deposits are insured by the government. 
For that reason households and most firms who hold bank deposits view those deposits as risk-free and need not worry about or attempt to monitor the opaque investments made by their bank that in turn finance the risky real assets in the economy. This creates a wellknown moral hazard problem where the bank is induced to overinvest in risky financial assets like loans and securities with high expected returns but also high risk. The end result is that the risks of the bank's assets are greater than the perceived (by depositors) risk of its deposit liabilities and equity. It also means that the risks generated on the real assets in the economy are greater than the perceived risks on the ultimate financial claims (i.e., insured deposits and non-insured claims) of savers against those assets. One easy way to see this is to assume the opportunity locus of real investments in the market portfolio of risky firms in the economy is concave in mean return and standard deviation of returns space like the efficient set in the CAPM, and that indifference curves of savers are convex in return-risk space. Savers would choose a point (an allocation of savings to the various risky assets in the market portfolio) on the concave mean-standard deviation efficient productive opportunity curve where the slope of their indifference curve --i.e., the marginal rate of substitution of expected return for risk-- equals the slope of the productive opportunity locus-i.e., the marginal rate of transformation between expected return and risk. ${ }^{10}$ When they turn a portion of their wealth over to banks the less risk averse managers of banks then choose a different allocation further up the productive opportunity locus with both higher (but diminishing) mean return and higher (and increasing) standard deviation of return or risk. At that point the marginal rate of transformation of return for risk on the market portfolio (an allocation of real capital to risky firms) is less than the marginal rate of substitution of return for risk in the 
indifference curve of savers who invested a portion of their savings in insured banks.

The end result is that more of the savings of depositors is invested in the risky sector and less in the risk-free sector than the depositors would have chosen had they made the investments directly themselves. This additional risk on the real assets in the economy does not disappear. The absorber of that risk differential are tax payers in the form of the deposit insuring agency or the Central bank when they pay off depositors of failed banks or share future losses when arranging mergers between troubled banks and healthy banks. To moderate this risk shifting that occurs on the asset side of the balance sheet of banks, government regulators have focused their attention on the liability and equity side of the balance sheet. Various Basle Accords on risk-based capital requirements have tried to mitigate this moral hazard problem by requiring banks to adjust the amount of their equity finance in response to changes in the risk of their portfolio strategy. However the opacity of the investments in their portfolio--partly the result of modern financial engineering — makes this almost an impossible task. The crisis of 2007-2009 suggests that the Basle risk-based capital requirements were too low. In any event under the present regulatory framework risky assets are subsidized in the sense that the return required per unit of risk by depositors who ultimately finance them is lower than it would be in the absence of deposit insurance. The chief beneficiaries of this risk subsidy recently have been households and risky business firms. Their cost of capital has been lower and their real investment higher than would have been the case in the absence of subsidized deposit insurance. Who loses from this subsidy to risk-taking? The government in that they have to pay a higher rate of interest on their risk-free debt, and 
then every so often they must pay out on their insurance claim and debt guarantees to the banking sector.

There are benefits and costs in the real economy associated with this subsidy for risktaking. On the benefit side more savings are allocated to risky investments, the kind of investments that in developing countries with stable legal and political environments can result in higher average rates of economic growth. New firms with innovative products have a better chance of coming to the economic surface when the financial system is tilted towards the financing of risky projects with high expected returns but also high risk. However the benefit of a higher rate of investment led economic growth in the expansion phase of the business cycle comes at the cost of a greater decline in real output growth in the ensuing recession as we are now experiencing in 2008-2009. The amplification of expansions and recessions partly caused by bank lending is a natural part of the economic landscape when the financial system is oriented towards the financing of risky real investments. One disadvantage of deposit insurance as a subsidy to risky real investments is that the amount of it depends on the risk perceptions and risk aversion of bank shareholders and the resulting portfolio decisions of bank managers. The risk perceptions and aversion of investors change over time. This is the problem the Federal Reserve and other Central Banks are confronting in 2008-2009 in their attempt to get banks lending again. Bad shocks that increase the risk perceptions and risk aversion of bank shareholders and thereby reduce the valuation of bank shares, are the market signal for banks to reduce their investments in risky loans and securities and switch to safe securities. Good external shocks that reduce the risk perceptions and risk aversion of bank shareholders and raise the market value of bank shares, are the market signal for 
bank managers to increase their investment in risky loans and risky securities and reduce their investments in safe securities. It is this volatility of bank lending and the real investment it finances that contributes to the amplification of the business cycle under the present fractional reserve private banking system with deposit insurance. Perhaps other forms of growth subsidies through the tax system that are less subject to volatile changes in risk perceptions and risk aversion of investors would be a more appropriate way to subsidize risky investment and growth.

Narrow banking has never had many advocates among academic economists. One reason for this is that its proponents have evidently not made a convincing economic argument that deposit-taking and risky lending — beside the fact they are separate activities - should be carried out by two or more types of financial institutions. One of the strengths of the advocates for the present system is that they have put forth at least one economic argument for combining the functions of deposit-taking and lending. One such argument is provided by Kashyap, Rajan, and Stein (2002). These authors begin by observing that deposit-taking and lending in the form of loan commitments (or overdraft privileges) both represent a demand for liquidity by individuals and firms in the economy. Both of these demands for liquidity require the providing institution to hold a stock of liquid assets themselves that in turn service these demands. From these two observations Kashyap, Rajan, and Stein then argue that if these two demands for liquidity are not perfectly correlated, it makes economic sense to combine deposit-taking and lending in the same type of financial institution, namely banks. The reason is that a smaller quantity of liquid assets can service both demands for liquidity when they are provided by a single entity compared to the case when they are provided by two or more 
entities. Liquid assets (eg., cash, reserve accounts with the Central bank, short-term riskless assets, etc.) in their model represent "costly overhead" that are required to service the demands for liquidity by depositors and lending commitments to borrowers. They argue this overhead is costly because: i) cash and until recently reserves yield a zero nominal return; ii) short-term riskless securities yield a nominal return but this return is subject to double taxation since currently banks are required to use the corporate form of business organization; and iii) borrowing from the corporate finance literature they argue that large stocks of liquid assets increases agency costs of the banks. For these reasons it is desirable that this costly overhead be reduced to a minimum which it will be if deposittaking and lending are carried out by a bank and the two demands for liquidity they service are not perfectly correlated. In other words, present day banks are low cost producers of liquidity services precisely because they service both demands. Were narrow banks mandated into existence the volume of loans per unit of "costly overhead" would be reduced with a loss in economic performance.

Their argument that a given stock of liquid assets can support a larger volume of lending when deposit-taking and lending are combined into a single entity is interesting. But does more loan finance for more real investment in the economy per unit of liquid assets always result in a social optimum? If that higher real investment is subsidized in some way, say through deposit insurance, the answer would be: No. Even more relevant is the question of whether the lending of the banks in their model is subject to credit risk. Their assumption (Kashyap et al., 2002, p.40) that loans made at date 0 and paid off at date 2 suggests that their loans are riskless and the only risks in the system are unexpected demands for liquidity from deposit withdrawals and real investment 
opportunities giving rise to loan commitments. Will their argument hold if the loans of their deposit-taking and lending banks are risky? If this is the case and absent deposit insurance, the deposit-taking and lending bank would be subject to a third demand for liquidity; namely, the demand for liquidity from depositors when they learn that the loans of their bank have suffered a reduction in value. On the other hand if the deposits are insured by government the end result is that this third demand for liquidity does not materialize and society ends up with a larger and riskier stock of real capital than it would have if deposit-taking and lending were separated as in the narrow banking proposal. Firms are generating less return per unit of risk than private savers require given their marginal rate of substitution between return and risk. Our conclusion is that the amount of real investment that produces an equality of the marginal rate of substitution of return for risk of savers with the marginal rate of transformation of return for risk of firms is a better indicator of social welfare than minimizing the costly overhead of holding the pieces of paper representing liquid assets.

How might a transition from our present banking system to a narrow banking system be implemented? The first thing to note is that our version of the narrow banking proposal, unlike Friedman's, only applies to transaction or checkable deposits rather than all the deposits that are currently protected by FDIC insurance. Balance sheet data for all commercial banks indicates that in May 2009 cash and reserve accounts at the Federal Reserve alone were equal to 114 percent of checkable deposits. It would appear that the banking system would not have to undergo a particularly difficult portfolio adjustment to achieve the portfolio required of narrow banks. The difficulty for existing banks would be spinning-off their risky loans and investments business along with their non-checkable 
deposits and other liabilities into separate non-bank financial institutions. It would be these non-bank financial institutions that would make business and consumer loans (including credit card loans) and invest in risky securities. ${ }^{11}$ The financing of these assets would be provided by various non-checkable claims. There are reasons to think the time period of the adjustment from the present day banking firm to narrow banks and nonbank financial intermediaries would not be overly long. One reason is that in the past it did not take banks very long to get into new financial services businesses once bank regulations were eased. Moreover the downsizing through spin-offs of existing banks (eg., Citigroup), non-bank financial enterprises (eg., Lehmann Bros.), and even nonfinancial firms (eg., GM and Chrysler) in the crisis of 2007-2009 appears not to be taking an inordinate length of time. Alternatively the risky loans and investments during the transition period could just be sold to investors like private equity groups and if economically viable later repackaged into publicly owned non-bank financial enterprises. The determinants of how long it would take the present banking system to evolve into narrow banks and non-bank financial intermediaries would depend on the volume of reserves held by banks, when the government would remove deposit insurance, and when banks would start charging for checking account services. For new narrow banks there would be no problem of adjusting from a risky portfolio of assets to a riskless portfolio.

What about individuals and firms that hold non-checkable deposits that are currently insured by FDIC? One reason deposit insurance was extended to these agents is that the government evidently felt obliged to provide a nominally risk-free interest bearing asset mainly for individuals and small firms that wanted a safe haven for their savings. If this is thought politically necessary the Treasury could provide non-marketable savings bonds 
in different denominations and maturities and terms that would parallel the maturities and terms of existing non-checkable deposits. These savings bonds could be sold at post offices, narrow banks, other financial institutions, and online directly from the Treasury.

Finally, how would the proposed narrow banks generate income in order to attract capital? One source of income would be interest earned on their deposit balances at the Federal Reserve. If narrow banks were allowed to hold risk-free short-term treasury securities, then the interest on these treasury securities would be another source of revenues. Still another source of revenue would be fees they would charge their checking account customers. To insure that checkable deposit customers would not be exploited in the form of high fees, there would be free entry into the narrow banking business subject only to the owners and manager being of good moral character. In this scheme nonfinancial firms could own narrow banks. Lastly narrow banks could earn an assortment of fees for providing various non-banking services for customers as they do now such as accounting and record keeping for small businesses, pension and trust services, providing safety deposit services and the like.

Of course moving to a narrow banking system would not completely eliminate the financial amplification of the business cycle. Non-bank financial institutions as well as individual investors operating in speculative securities markets are subject to the same swings in risk perceptions and investor sentiment in response to external shocks as banks. How might the swings in risk perceptions and risk aversion in non-bank financial institutions and financial markets be moderated in order to reduce the amplification of the business cycle caused by the financial system? For non-bank financial institutions such as finance companies, investment banks, and any other financial institution whose 
financing involves significant counterparty risk, we propose that simple Basle I type capital requirements should be imposed on the non-banks for the same reason they were imposed on banks. The same would apply to various types of insurance companies. The objective of those requirements would be to balance portfolio risk with financing risk. The riskier the assets contained in the portfolios of non-bank financial institutions, the more equity capital (or less leverage) should be required to finance the portfolio. There are two administrative ways to achieve this variation in financial leverage. One way discussed below is to re-impose selective credit controls such as margin requirements at the discretion of the Central Bank. The other administrative way is through a Basle-like risk-based capital requirement. What exactly the Basle-like risk-based capital requirements for different non-bank financial institutions should be in order to reduce contagion risk in the financial system must be the subject of future research. One

possibility is to simplify the requirements by having only two asset categories: i) riskless assets requiring a relatively low equity leverage ratio on total assets; and ii) risky assets requiring a much higher equity leverage ratio. In light of the 2007-2009 crisis it would appear that a 4-5 percent equity leverage ratio or tier1 requirement on risk-based assets and an 8-10 percent tier 1 plus tier 2 requirement are wholly inadequate.

\section{Policies for Stabilizing Speculative Asset Prices}

Financial assets traded in markets are another source of financial instability that can spill over to the real economy and amplify business cycles. Volatility in stock valuations induces volatility in real corporate investment, consumption and GDP as the evidence of Barro (1990), Panageas (2003), Baker et al. (2003), Kau et al. (2004), Polk and Sapienza (2004), Gilchrist et al. (2005), and Chirinko and Schaller (2007), among others indicates. 
Some of this volatility in financial asset markets is the result of financing speculative asset portfolios with debt. To the extent this is the case one proposal to partially moderate this volatility is for the government to cyclically vary the tax deductibility of interest payments for all investors (except non-financial firms) transacting in speculative asset markets. A second way to dampen volatility in certain asset markets is for the Federal Reserve to use its selective controls over margin requirements and minimum down payments for the stock markets and real estate markets in a pro-active way. The general idea would be to raise margin requirements and down payments when these markets are deemed "exuberantly" high, and reduce them when they are low. To this list of assets we would add certain commodities whose prices are subject to speculative bubbles. The margin requirements for all speculative asset transactions should apply to all individual investors and non-bank financial enterprises that are allowed to borrow such as investment banks, hedge funds, closed-end mutual funds, and private equity funds. These selective controls could substitute for or compliment the Basle Accord on risk-based capital. Moreover during a downturn in these markets this could be reinforced by keeping the prohibition against "naked" short-selling (selling an asset without first borrowing it), and reinstating the "uptick" rule for short sales. ${ }^{12}$ Before 2007-2009 these proposals were unthinkable and ones not advocated by the regulatory authorities who have jurisdiction over these rules. However, some of them have emerged as policy albeit for a short time period in the crisis. When the short selling ban on financials in September 2008 was in effect, it blunted the collapse in share prices of various financial institutions (Harris et al., 2009, and Gagnon and Witmer, 2009). It is sometimes argued that investors got around these rules when put options were available on stocks where 
short selling was banned. Even if that were the case it would seem that it would be a more expensive way to circumvent a ban on short selling still making the ban somewhat effective. Just as wars allow the medical profession to experiment, the crisis of 20072009 allowed the Federal Reserve and the regulatory authorities to experiment. If the emergency rules were helpful in saving the financial system when it was in crisis, it would seem they could be helpful in preventing a financial crisis in the first place.

A second way to moderate fluctuations in the prices of speculative assets like common stocks is for the Federal Reserve to carry out stabilizing open market operations in an index of the market portfolio (where the unsystematic risk of the portfolio is reduced to some minimum) of equity shares. Similar proposals have been made by Fischer and Merton (1984, pp. 93-94), and Krainer (2003, pp.285-288) among others. The form this investment in the market portfolio might take would be purchases and sales of index mutual funds like the Vanguard 500. Alternatively they could form a broader index mutual fund themselves. One way to implement this stabilizing strategy would be to establish a long-run trend for share prices based on the long-run permanent earnings of the business sector. Around this trend the Federal Reserve could establish an $\alpha$-percent (eg., $5 \%, 10 \%, \ldots)$ filter band that would depend in some way on the magnitude of transitory earnings of the business sector. If the index of the market portfolio fell below (or above) the lower (or upper) $\alpha$-percent band, the Federal Reserve would buy (or sell) the mutual fund holding the index of the market portfolio until it reached the lower (or upper) band. Again, before 2007 the suggestion that the Central Bank should buy and sell an index fund of risky assets like equities would be viewed by most economists as irresponsible. Since 2007 this suggestion in retrospect seems to be somewhat bland and 
perhaps overly conservative because Central Banks like the Federal Reserve have already purchased billions of dollars of risky assets. These purchases were not in the form of a diversified efficient market portfolio designed to minimize unsystematic risk and stabilize the market as a whole as suggested above, but instead they were the securities of individual firms in grave financial difficulties. The financial maelstrom beginning in 2007 put Central Banks and Fiscal Authorities on a war-like footing. The conventional views on moral hazard for conventional times, and the scope of the roles of Central Banks and Fiscal Authorities in free enterprise economies were thrown to the wind. Only in the case of the investment bank Lehman Brothers did the Federal Reserve and Treasury bring up the well-known arguments of moral hazard when denying that firm the financial accommodation granted to other financial institutions; and in retrospect that denial was viewed as a policy mistake due to the counterparty risk it unleashed. How were these subventions in various enterprises received by the stock market? Did the market collapse when financial institutions were rescued in various ways because of concerns about moral hazard problems and the long-run viability of capitalism? When the U.S. House of Representatives defeated the $\$ 700$ billion financial rescue plan in late September 2008, the Dow Jones Industrial Average fell 777.68 points, the largest one day drop in stock prices in history (WSJ.com, September 30, 2008). Soon after this strong statement by the stock market the rescue plan was passed by the House. It would appear that at that time the market was not opposed to taking on more moral hazard risk in the form of bailouts even if they threatened the core values of capitalism.

What advantages might be expected from Central Banks carrying out open market operations in a portfolio of equities in the way described above? After all if markets 
were perfectly efficient, purchases and sales of short-term riskless assets like T-Bills would quickly be arbitraged out to the corporate bond and stock markets without the Central Bank having to deal directly in those markets. It would therefore seem that one of the implicit assumptions underlying this proposal is that financial markets are not perfectly efficient. The particular form of market imperfection underlying this proposal is that market prices often overshoot their intrinsic valuations. According to DeLong et.al (1990) and Schleifer (1996) these departures of market prices from intrinsic valuations cannot be easily arbitraged away by rational and sophisticated traders because of their own risk aversion, their limited access to financial capital, and the fact that these sophisticated traders are monitored by less sophisticated principals who determine their remuneration. Accordingly the Central Bank is in a position to overcome these imperfections and move market prices closer to their efficient intrinsic valuations not to mention the profit that would accompany this strategy. The Federal Reserve in principle should have low risk aversion and, as we have recently seen, access to large amounts of financial capital. While they are monitored by less sophisticated but powerful principals like the President and the Congress, they are protected by an Act of Congress, fixed term appointments, and powerful friends in the financial system. It would therefore seem that while this policy could possibly increase volatility within the $+/-\alpha$ percent filter bands if traders learned these bands, it would eliminate "excessive" fluctuations in the general level of stock prices outside the filter bands. And by eliminating excessive fluctuations in the stock market they would move towards smoothing out fluctuations in real investment and economic activity. 
How might this work in practice? For example suppose there is a negative shock that occurs when rating agencies grossly mis-judge for the first time the quality of complex and opaque financial products. This negative information shock could be expected to raise the risk perceptions and risk aversion of investors both of which raise their required rate of return and drive down the price of risky securities below the lower $\alpha$-percent filter band established by the Central Bank. As private investors with high and rising risk aversion are fleeing to safety by getting out of the market, the Central Bank with low risk aversion is getting into the market thereby cushioning the fall in the market valuations of risky securities like equities. In the end the cost of equity capital does not rise as much as it would have absent the intervention by the Central Bank and risky real investment and economic activity does not fall as much as it would have absent the intervention. The reverse would occur in the wake of a good shock as irrational exuberance takes hold driving stock prices towards the $\alpha$-percent upper band set by the Central Bank. With this open market strategy the Central Bank could go a long way in achieving its goal of stabilizing securities markets that are periodically overshooting and undershooting their intrinsic value and reducing the amplification of the business cycle caused by changing risk perceptions and risk aversion of investors in the financial system.

What problems and criticisms might this proposal for open market operations in risky equities have to confront? One criticism is that it might result in government ownership of various firms much like what is happening in mid-2009. Most economists, noneconomists, and the government itself are uncomfortable with the prospect of government taking an ownership position in the automobile, banking, and insurance businesses. This criticism would not apply to the above proposal. The proposal is for the government in 
the form of the Central Bank to buy and sell index mutual funds that in turn would buy and sell the individual equities comprising the index. The index mutual funds would vote the individual stocks on matters of concern to the shareholders much as they do now.

A second criticism might be that large Central Bank inflows and outflows of funds to these index mutual funds in order to keep stock market averages within some $\alpha$-percent filter band might discourage some "smart money" from trading in the market. This in turn would leave more trading in the hands of so-called "noise" or uninformed traders to establish relative prices. If this would occur the relative prices of equities that would emerge might not reflect all the relevant information pertaining to their intrinsic valuations. The end result is that real investment might be inefficiently allocated across the different sectors in the economy. A related criticism would be that to the extent the index that mutual funds would be investing in fell short of some true market portfolio containing all the traded securities of firms in the economy, there could result a misallocation of real investment between the firms in the index and those firms outside the index. The end result would be that the volatility of security prices, real investment, and output of firms outside the index would increase relative to the real investment and output of firms inside the index. Of course to the extent sophisticated traders remained in the market they would arbitrage away any differences between the share prices of firms within and outside the index purely resulting from Central Bank injections and withdrawals of funds into the aggregate securities market. The important question is what effect this policy change will have on the amount of "smart" money in the equity markets. If smart money enters markets where there are arbitrage opportunities, then pricing discrepancies between firms inside and outside the index should provide the 
necessary incentives. These are of course empirical questions that await empirical answers from future research.

Finally in the end this policy recommendation would seemingly put more power in the hands of the Central Bank and perhaps Treasury to stabilize the economy. It is one thing to have the Central Bank carry out open market operations in "T-Bills mostly" and have the effect spread to the corporate bond and stock markets by many private traders, and it is quite something else to have them deal directly in these markets. They would be under considerable political pressure not to stop a stock market boom fueled by irrational exuberance, itself a concept that is hard to define objectively. On the other hand, equally important if not more difficult decisions are taken routinely by the Supreme Court and other branches of government using their subjective judgment and interpretation of the law in some current situation. Why can't it be so with the Central Bank?

\section{SUMMARY AND CONCLUSIONS}

The 2007-2009 financial and economic crisis has been a remarkable event. The fact that financial economists (who helped create the advanced and complicated financial architecture that some blame for facilitating the crisis) along with stabilizing and regulatory government organizations such as the Federal Reserve and the Treasury Department for the most part did not see it coming is remarkable. The fact that many of these same financial economists and government organizations are now offering solutions to this and future crises is also remarkable. ${ }^{13}$ Not being deterred by this incongruity we have in this paper outlined several suggestions for reforming the financial system in 
advanced economies with developed financial markets. These suggestions for reform are not particularly new although they have not surfaced in recent discussions on regulatory policy. The main suggestions were to: i) move towards a narrow banking system ${ }^{14}$, ii) reinstate selective credit controls over purchases of real estate, certain commodities, and corporate securities for all financial investors, and iii) have the Central Bank carry out open market operations in a market portfolio of risky stocks with the view of stabilizing fluctuations in the price level of these securities. These suggestions are based on the theoretically and empirically documented premise that some markets for speculative assets and the present day banking system amplify cyclical fluctuations in real economic activity and employment. The 2007-2009 crisis is just the latest and most severe in a series of finance driven crises since World War II. Our financial system driven by sudden shock-induced fluctuations in risk perceptions and risk aversion is proving to be an expensive externality for the real economy, and externalities are one justification for government intervention and regulation. Unemployment rates reaching 10 percent are a very high price to pay to allow financial innovation to out-pace financial regulation. The objective of our proposals is to moderate the amplifying effect of the financial system on the real economy. This means dampen expansions as well as recessions. The ultimate question is whether citizens are prepared to pay the price of the former to achieve the goal of the latter. If not the demand and supply of present day bailouts will continue unabated and our economic system will come closer to one of privatizing gains in good states of nature but socializing losses in bad states. Ultimately this will undermine the philosophical and ethical foundations of a free enterprise system. 


\section{ENDNOTES}

1. Earlier advocates of the 100 percent reserve requirement were Henry Simons (1934) and Irving Fisher (1935). In Friedman's version the 100 percent reserve requirement would apply to all deposits; checking accounts, retail money market mutual fund accounts at banks, savings deposits, and small time deposits

2. The balance sheet data for the Federal Reserve Bank was obtained from a speech given by the Chair Ben Bernanke at the Federal Reserve Bank of Richmond 2009 Credit Market Symposium on April 3, 2009.

3. Procyclicality of bank lending has been observed in the banking literature for quite some time. Reasons for this behavior are regulatory factors such as the various Basle Accords and various non-regulatory factors. A partial listing of the former would include Bernanke and Lown (1991), Lang and Nakamura (1995), Berger and Udell (1994), Hancock and Wilcox (1994), Peek and Rosengren (1995), Shrieves and Dahl (1995), Stanton (1998), Wagster (1999), Borio et al. (2001), Estrella (2004), Pennacchi (2005), and Catarineu-Rabell et al. (2005) among many others. A partial listing of non-regulatory causes would include Bernanke and Gertler ( 1989), Rajan (1994), Bernanke et. al. (1996), Kiyotaki and Moore (1997), Berger et al., 2001), Berger and Udell (2003), Gorton and He (2005), Krainer (2009), and Abiad et al.(2009).

4. There is a large literature indicating that the risk premium and Sharpe ratio are countercyclical both of which are consistent with time varying risk aversion. Theoretical contributions include Campbell and Cochrane (1999), Chan and Kogin (2002), and Bekaert et al. (2006). Ex-post empirical work includes Fama and French (1989), Ferson and Harvey (1991), Harrison and Zhang (1999), Harvey (2001), and Bekaert et al. (2009) among many others.

Graham and Harvey (2009) provide evidence on the inter-temporal movement in the ex-ante equity risk premium over the period 2000Q3-2009Q2. Over this time period they survey on average 300 Chief Financial Officers of U.S. firms to get their estimate of the future 10 year expected returns on the $\mathrm{S} \& \mathrm{P}$ 500 stock index. From this expected return on equity they subtract the yield on 10 year T-bonds. For the period 2002Q2-2004Q2 the median risk premium was 3.73 percent. For the 10 quarter run-up to the crisis $2004 \mathrm{Q} 3-$ 2006Q4 the median risk premium fell to 2.66 percent for a reduction of 1.07 percent. For the 10 quarter crisis period 2007Q1-2009Q2 the median risk 
premium rose to 3.63 percent for an increase of .97 percent. This suggests that risk aversion fell in the 10 quarter run-up to the crisis and then rose during the crisis period.

5. The growth in the profitability of the financial sector in the post WW II period has been extraordinary. In 1948 profits in the financial sector were roughly $\$ 3$ billion or slightly less that 10 percent of total corporate profits. The peak was reached in 2002 when profits (ex bonuses) in the financial sector were $\$ 398$ billion or 45 percent of total corporate profits. What did society get for those high profits and large bonuses? According to the finance and growth literature (Levine, 2005) a well-developed and efficient financial system facilitates the transfer of financial resources from savers to investing firms which presumably stimulates growth enhancing real business investment. It does this by reducing asymmetric information and moral hazard problems between savers and investors. What has actually happened to non-residential investment over this 54 year period? In 1948 non-residential investment was \$26.8 billion or 10 percent of GDP. In 2002 non-residential investment was $\$ 1,066$ billion or 10 percent of GDP. The payoff to a developed country like the U.S. from a sophisticated and highly profitable financial system was evidently not in a commensurate relative increase in total company investment nor as we will see in the productivity of that investment. Of course the equipment and software component of business investment relative to GDP did grow from 6.4 percent of GDP in 1948 to 7.4 percent in 2002 (reaching a maximum of 8.4 percent in 1979), but that was more the result of a general increase in the use of computers and software. What about growth in the real economy as measured by the average percentage rate of growth of real GDP and the growth in multifactor productivity? Splitting the 1960-2008 period in half the average growth rate in real GDP for the period 1960-1983 was 3.41 percent and for the period 1984-2008 it was 3.25. Finally, was financial development associated with increases in multifactor productivity as measured by the Bureau of Labor Statistics? For multifactor productivity the average growth rate was 2.45 percent for the period 1960-1983, and for the period 1984-2008 it was 2.23 percent. It would appear that the growing profits and bonuses in the financial sector were not associated with higher growth rates in real output or multifactor productivity. On the other hand it is true that the modern financial architecture in the form of securitization of home mortgages and credit card debt has moderated the effect on household consumption and investment of the growing inequality in real income that has occurred in the U.S. for the past 25 years. The working poor have had increased access to credit. It is ironic that it was the borrowing of this group that brought on the sub-prime crisis in 2007 destroying some of the wealth of those more fortunate than themselves over the past 25 years.

6. There is no general agreement on what types of assets banks would be allowed to hold under the various narrow bank proposals. At one end of the spectrum the Friedman-Simons plan had banks holding cash and reserve 
accounts at the Federal Reserve. Litan (1987) proposes that the assets be restricted to U.S. Treasury securities and federally guaranteed securities. Pierce (1991) proposes narrow banks should be restricted to short-term Treasury securities and highly rated short-term commercial paper. Krainer (2002) would only allow banks to invest in cash, reserves, and short-term TBills. Finally, Bryan (1991) at the other end of the spectrum would allow banks to invest in short-term Treasury securities, high quality short-term commercial paper, and loans to small businesses and individuals. All of these proposals are better than the assets banks are currently allowed to buy although we now personally favor the original Friedman-Simons plan of restricting investments to cash and reserve accounts at the Central Bank. One advantage is that it would leave the maximum amount of Treasury securities available for investors to attain their optimal mix of risky and riskless investments in their portfolios.

7. For the number of banks and bank branches see Jones and Critchfield (2005) and Spieker (2004). For the private estimate of the number of post offices in the U.S. see http://www.postalhistory.com/Post_offices/index.htm

8. There is a question of what to do about money market mutual funds which offer limited checking account services. We agree with Boyd and Jagannathan (2009) that they should be given a choice. If they continued to offer limited checking account services they would be included and subject to the same regulations as narrow banks. If they eliminated their checking account services they would be classified as an ordinary mutual fund.

9. It has been observed in the popular press in the U.K. that private banks have been very slow in introducing known technologies that would greatly speedup check clearing. The reason often given is that implementing these technologies is less profitable than developing complex financial products. See "The Slow Drip of the Faster Payments System," by John Kay in the Financial Times, June 17, 2009, p. 9. The argument that government regulation always produces a chilling effect on innovation seems to be the last refuge of a banker to paraphrase Dr. Johnson.

10. Stiglitz (1972) describes this condition for Pareto efficiency in an economy where investment is allocated to different risky firms according to the meanvariance CAPM.

11. Are banks better monitors of loans to firms and individuals than non-banks such as finance companies, insurance companies, or other non-bank mutual funds that would emerge out of a narrow banking system? To be sure one advantage is that present day banks have access to checking account balances of loan customers. However, if this is thought to be important a covenant requiring the borrower to provide checking account balances at whatever 
frequency is thought necessary could easily be inserted in any loan contract between the borrower and the lending non-bank financial institution. The fact that finance companies make business and consumer loans in competition with present day banks indicates that monitoring disadvantages for non-banks would not be much of a problem. For a careful empirical analysis reaching the same conclusion for banks and finance companies see Carey et al., 1998.

12. In an interesting experimental setting with "smart" traders and "noise" traders, Bhojraj et al. (2009) illustrate that placing more capital in the hands of smart traders by relaxing margin requirements will reduce equilibrium overpricing, but at the expense of attenuating observed overpricing by slowing the convergence to equilibrium. This is because any given smart arbitrager cannot predict the trading strategies of other smart arbitragers thus giving rise to the phenomena of synchronization risk. The delay in convergence to equilibrium prices occurs because it is more profitable to first "front-run" the noise traders and then delay the equilibrating arbitrage trades relative to other smart traders. Early short-selling arbitragers run the risk of a margin call before prices reach their lower equilibrium level. One unintended consequence of a ban on short selling is that it transfers wealth from buyers to sellers. For an analysis of this effect see (Harris et al., 2009).

13. There has developed in the past several years a huge literature dealing with various causes of the current crisis along with suggestions for reforming the U.S. financial system in hopes of preventing future crises. Some (but far from all) suggestions have found their way into the 88 page Treasury document "FINANCIAL REGULATORY REFORM, A NEW FOUNDATION: REBUILDING FINANCIAL SUPERVISION AND REGULATION," Department of the Treasury, June 2009. The recommendations in this document are organized around the following five principles: i) Promote robust supervision and regulation of financial firms; ii) Establish comprehensive regulation of financial markets; iii) Protect consumers and investors from financial abuse; iv) Provide government with the tools it needs to manage financial crises; and v) Raise international regulatory standards and improve international cooperation. This report at present (August 2009) is somewhat short on details and is primarily devoted to identifying where the financial system failed in the run-up to the crisis, and how best to resolve a crisis once it has started. One proposal that is specific enough to be criticized is the so-called Systemic Risk Authority that would give the Federal Reserve the authority to regulate any and all financial institutions that pose a threat to systemic risk. What exact form that regulatory authority will take is not known at this point. It would appear (in the summer of 2009) that Congress will be reluctant to grant such broad regulatory powers without subjecting the Federal Reserve itself to a greater degree of Congressional oversight.

14. It will be argued that removal of the explicit government safety net on depository institutions will just push the implicit safety net further on to 
whatever group of financial institution gets into trouble in the next financial crisis. The orchestrated workout of Long-Term Capital Management by the Federal Reserve in 1998, the rescue of various types of nonbank financial institutions and even non-financial enterprises in the recent crisis will be argued to be evidence supporting this view. This need not be so. Government in this current crisis did not save the hedge funds, private equity funds, or sovereign wealth funds that provided equity financing to the banking sector during the early stages of the crisis only to see those equity valuations evaporate in the later stages of the crisis. Nor did the government save the many types of mutual funds and pension funds investing in equity securities when equity prices collapsed in 2008 erasing trillions of dollars of investor wealth. Why should mutual funds investing in private risky equity type securities be treated differently than mutual funds investing in private risky debt securities?

\section{References}


Abiad, A., R. Balakrishnan, P. Koeva Brooks, D. Leigh, and I. Tytell. 2009. "What's the Damage? Medium-term Output Dynamics After Banking Crises." IMF Working Paper WP/09/245.

Baker, M., J. Stein, and J. Wurgler. 2003. "When Does the Market Matter? Stock Prices and the Investment of Equity Dependent Firms." Quarterly Journal of Economics 118, pp.969-1006.

Barro, R. 1990. “The Stock Market and Investment.” Review of Financial Studies 3, pp. 115-132.

Bekaert, G., E. Engstrom, and S. Grenadier. 2006. "Stock and Bond Investors with Moody Investors.” NBER Working Paper No. 12247.

Bekaert, G. M. Hoerova, and M. Scheicher. 2009. "What Do Asset Prices Have to Say About Risk Appetite and Uncertainty." European Central Bank Working Paper No. 1037.

Berger, A. and G. Udell. 1994. "Did Risk-Based Capital Allocate Bank Credit and Cause a Credit Crunch in the United States?” Journal of Money, Credit, and Banking 26, pp. $585-628$.

Berger, A. M. Kyle, and J. Scalise. 2001. "Did U.S. Bank Supervisors Get Tougher During the Credit Crunch? Did They Get Easier During the Banking Boom?, Did it Matter to Banking Lending?" in Mishkin, F. (Editor) Prudential Supervision: What Works and What Doesn't. Chicago: University of Chicago Press.

Berger, A. and G. Udell. 2003. "The Institutional Memory Hypothesis and the Procyclicality of Bank Lending Behavior." Journal of Financial Intermediation 13, pp. 458-495.

Bernanke, B. and M. Gertler. 1989. "Agency Costs, Net Worth, and Business Fluctuations.” American Economic Review 79, pp. 14-31.

Bernanke, B. and C. Lown. 1991. "The Credit Crunch.” Brookings Papers on Economic Activity 2, pp. 205-247.

Bernanke, B., M. Gertler, and S. Gilchrist. 1996. "The Financial Accelerator and the Flight to Quality." Review of Economics and Statistics 78, pp. 1-15.

Bhojraj, S., R. Bloomfield, and W. Tayler. 2009. "Margin Trading, Overpricing, and Synchronization Risk.” Review of Financial Studies 22, pp. 2059-2085.

Borio, C., C. Furfine, and P. Lowe. 2001. "Procyclicality of the Financial System and Financial Stability: Issues and Policy Options." Bank for International Settlements, BIS Papers, No. 1. 
Boyd, J. and R. Jagannathan. 2009. “Avoiding the Next Crisis.” The Economists Voice. www.bepress.com/ev

Bryan, L. 1991. “Core Banking.” The McKinsey Quarterly No. 1, pp. 61-74.

Carey, M., M. Post, and S. Sharpe. 1998. "Does Corporate Lending by Banks and Finance Companies Differ? Evidence on Specialization in Private Debt Contracting." Journal of Finance 53, pp. 845-878.

Catarineu-Rabell, E., P. Jackson, and D. Tsomocos. 2005. "Procyclicality and the New Basle Accord-Bank's Choice of Loan Rating System.” Economic Theory 26, pp.537-557.

Campbell, J. and J. Cochrane. 1999. "By Force of Habit: A Consumption-Based Explanation of Aggregate Stock Market Behavior." Journal of Political Economy 107, pp. 205-251.

Chan, Y. and L. Kogin. 2002. "Catching Up with the Jones: Heterogeneous Preferences and the Dynamics of Asset Prices." Journal of Political Economy 110, pp.1255-1285.

Chirinko, R. and H. Schaller. 2007. "Fundamentals, Misvaluation, and Investment: The Real Story." Unpublished Working Paper available on the SSRN at http://ssrn.com/abstract $=965415$

DeLong, J., A. Shliefer, L. Summers, and R. Waldmann. 1990. "Noise Trader Risk in Financial Markets." Journal of Political Economy 98, pp. 703-738.

Estrella, A. 2004. "The Cyclical Behavior of Optimal Bank Capital." Journal of Banking and Finance 28, pp.1469-1498.

Fama, E. and K. French. 1989. "Business Conditionsand Expected Returns on Stocks and Bonds." Journal of Financial Economics 25, pp.23-49.

Ferson, W. and C. Harvey. 1991. "The Variation of Economic Risk Premium." Journal of Political Economy 99, pp. 385-415.

Fischer, S. and R. Merton. 1984. "Macroeconomics and Finance: The Role of the Stock Market." Carnegie-Rochester Conference Series on Public Policy 21, pp.57-108.

Fisher, I. 1935. 100 Percent Money. New Haven: The City Printing Company, 1935.

Friedman, M. 1959. A Program for Monetary Stability. New York: Fordham University Press, 1959.

Gagnon, L and J. Witmer. 2009. "Short Changed? The Market's Reaction to the Short Sale Ban of 2008." Unpublished Working Paper available on the SSRN at http://ssrn.com/abstract=1421490. 
Gilchrist, S., C. Himmelberg, and G. Huberman. 2005. "Do Stock Price Bubbles Influence Corporate Investment?” Journal of Monetary Economics 52, pp. 805-827.

Gorton, G. and P. He. 2007. "Bank Credit Cycles." Working Paper available on the SSRN at http://ssrn.com/abstract=720721.

Graham, J. and C. Harvey. 2009. "The Equity Risk Premium Amid a Global Financial Crisis." Unpublished Working Paper available on the SSRN at http://ssrn.com/abstract=1405459.

Hancock, D. and J. Wilcox. 1994. "Bank Capital and the Credit Crunch: The Roles of Risk-Weighted and Unweighted Capital Regulations." Journal of the American Real Estate Urban Economic Association 22, pp.59-94.

Harris, L., E. Namvar, and B. Phillips. 2009. "Price Inflation and Wealth Transfer During the 2008 SEC Short-Sale Ban." Working Paper available on the SSRN at http://ssrn.com/abstract $=1364390$

Harrison, P. and H. Zhang. 1999. "An Investigation of the Risk and Return Relation at Long Horizons." Review of Economics and Statistics 81, pp.399-408.

Harvey, C. 2001. "The Specification of Conditional Expectations." Journal of Empirical Finance 8, pp.573-637.

Jones, K. and T. Critchfield. 2005. "Consolidation in the U.S. Banking Industry: Is the Long Strange Trip About to End?” FDIC Banking Review 17.

Kashyap, A., R. Rajan, and J. Stein. 2002. "Banks as Liquidity Providers: An Explanation for the Co-Existence of Lending and Deposit-Taking." Journal of Finance 57, pp. 33-73.

Kau, J., J Linck, and P. Rubin. 2004. “Do Managers Listen to the Market?” Unpublished Working Paper available on the SSRN at http://ssrn.com/abstract=610062.

Kiyotaki, N. and J. Moore.1997. “Credit Cycles.” Journal of Political Economy 105, pp. 211-248.

Krainer, R. 2002. "Banking in a Theory of the Business Cycle: A Model and Critique of the Basle Accord on Risk-Based Capital Requirements for Banks." International Review of Law and Economics 21, pp. 413-433.

Krainer, R. 2003. Corporate Finance, Governance, and Business Cycles: Theory and International Comparisons Amsterdam: North-Holland.

Krainer, R. 2009. "Portfolio and Financing Adjustments for U.S. Banks: Some Empirical Evidence." Journal of Financial Stability 5, pp. 1-24. 
Lang, W. and L. Nakamura. 1995. "Flight to Quality in Bank Lending and Economic Activity.” Journal of Monetary Economics 36, pp. 145-164.

Levine, R. 2005. "Finance and Growth: Theory and Evidence," in Aghion, P. and S. Durlauf (editors), Handbook of Economic Growth, Volume 1A. Amsterdam: Elsevier North-Holland, pp. 865-934.

Litan, R. 1988. What Should Banks Do? Washington, DC.: Brookings Institute.

Panageas, S. 2003. "Speculation, Overpricing, and Investment- Theory and Evidence." Unpublished Working Paper, Wharton School, University of Pennsylvania.

Peek, J. and E. Rosengren. 1995. "Bank Regulation and the Credit Crunch." Journal of Banking and Finance 19, pp.679-692.

Pennacchi, G. 2005. "Risk-Based Capital Standards, Deposit Insurance, and Procyclicality.” Journal of Financial Intermediation 14, pp. 432-465.

Pierce, J. 1991. The Future of Banking. New Haven: Yale University Press for the Twentieth Century Fund.

Polk, C. and P. Sapienza. 2004. "The Real Effects of Investor Sentiment.” NBER Working Paper No. 10563.

Rajan, R. 1994. "Why Bank Credit Policies Fluctuate: A Theory and Some Evidence." Quarterly Journal of Economics 109, pp.399-441.

Shleifer, A. 1996. "Inefficient Markets.” Clarendon Lectures. Oxford University, May 79, 1996.

Shrieves, R. and D. Dahl. 1995. "Regulation, Recession, and Bank Lending Behavior: The 1990 Credit Crunch.” Journal of Financial Services Research 9, pp. 5-30.

Simons, H. 1934. "A Positive Program for Laissez-Faire: Some Proposals for a Liberal Economic Policy." Public Policy Pamphlet No. 15. Chicago: University of Chicago Press.

Spieker, R. 2004. “Bank Branch Growth Has Been Steady_-Will it Continue?” FDIC Research Paper, Division of Insurance and Research, Federal Deposit Insurance Corporation.

Stanton, S. 1998. "The Underinvestment problem and Patterns of Bank Lending." Journal of Financial Intermediation 7, pp. 293-326. 
Stiglitz, J. 1972. "On the Optimality of the Stock Market Allocation of Investment." Quarterly Journal of Economics 86, pp. 25-60.

Wagster, J. 1999. "The Basle Accord of 1988 and the International Credit Crunch of 1989-1992.” Journal of Financial Services Research 15, pp. 123-143. 